\title{
12
}

\section{Juridification, Marginalised Persons and Competence to Mobilise the Law}

\author{
Knut Papendorf
}

\section{Introduction}

Access to the law for marginalised, disadvantaged or, in this context, what may be termed law-dissociated groups, and their capacity to mobilise the law, are central to research on legal aid. Experienced lawyers assert that 'being right is insufficient, one must also be granted rights.' This is a recurring theme amongst experienced lawyers with a legal aid portfolio, i.e., a practice used by 'non-paying clients dependent on either free legal advice or finding a lawyer willing to work nearly for free.' If clients fail to get such advice, they often do not take their disputes further, because of the not insignificant economic risks involved in a suit. This cements the asymmetry that already exists between private actors on the one side and the public authorities on the other. These lawyers describe their clients as being in a situation of double powerlessness, which arises from their lack of competence and economic opportunities (Papendorf 2012, p. 138).

\footnotetext{
K. Papendorf $(\bowtie)$

Department of Criminology and Sociology of Law, University of Oslo, Oslo, Norway 
This claim will be discussed below in the context of the more general judicial development represented by the extensive juridification of society. In Norway (and the other Scandinavian countries) there is a tradition of setting in train an extensive research effort every 20-30 years in order to analyse power relations and the state of democracy in the various countries. The most recent such research effort in Norway-carried out by the Research Group on Power and Democracy ${ }^{1}$ (1998-2003)- - has indeed renewed this debate on juridification. Øyvind Østerud, the head of this research group, has identified juridification as a problem for democracy. According to Østerud (2006, p. 112f), ${ }^{2}$ a combination of rights legislation, government directives, and municipal budget scarcity may produce unintended redistribution: 'When means are scarce, it becomes crucial to have the support of resources and strong spokesmen.'

The work of the research group and its final report in particular, has undoubtedly led to a new consideration of juridification, its underlying notions and consequences for the rule of law-and more concrete questions concerning access to the law. One may ask whether access to the law for particularly law-dissociated members of society has deteriorated or improved as juridification takes place. The research group's analysis includes evidence for both possible views. This makes an interesting starting point for a more thorough examination of the views of the research group on juridification and its consequences for access to the law for lawdissociated groups in society. Juridification must itself be seen in a wider context, namely the debate on the limitations of modern law from an administrative perspective which, again, has consequences for the capacity to mobilise the law.

The Norwegian Research Group on Power and Democracy, which resulted from the parliamentary decision of December 1997, worked from 1998 until 2003. The first item of the research group's mandate is described as follows:

The main theme is principles of the Norwegian democracy and changes in these ... The starting point is the Norwegian social model built on representative democracy ... Important conditions for representative democracy include that the individual having a voice, and there being local and central government bodies which are representative and have legitimacy and authority. (Østerud et al. 2003, p. 3) 
A major conclusion of the research group's final report is that democracy is withering, partly as a result of juridification: ever greater parts of society are regulated by laws and directives, thus increasing the decisionmaking capacities of judicial bodies at the expense of politics and government (NOU 2003, p. 19).

First of all, the research group points out a new pattern of welfare distribution on the basis of what they see as parliament's increased use of rights legislation within the areas of health, welfare, and education. What was previously decided by, among other things, municipal political debate is now determined by interpreting rights legislation. They argue that the power of jurists, particularly that of lawyers and the courts, has increased (NOU 2003, p. 19, 31). Second, they describe increasing juridification associated with supranationalisation: the implementation of the EEA-agreement, international human rights, and internationalisation of commercial and contract law lead to the diminution of elected bodies' space for action. The power of interpretation and balancing of contradictory rights is transferred to the judicial system and courts. (ibid., p. 14)

In what follows, I will primarily concentrate on the first-nationalperspective, examining the different forms of juridification as regards three social actors: the legislator, administration, and judiciary. Then the research group's view on juridification will be concretised and the positive and negative conceptual content of juridification will be presented. Thereafter, Habermas' concept of juridification and his legal policy proposals will be discussed in the light of Norwegian research on legal aid. Next, I will look at how Weber's formal legal rationality developed into the procedural rules of the welfare state and its consequences for those seeking justice. The article ends with a conclusion in relation to mobilising the law.

\section{The Theory of Juridification and Law- Dissociated Seekers of Justice}

As a first step, I will clarify the concept of juridification. ${ }^{3}$ Three different forms of juridification can be seen in three different producers or social actors. The first is the legislator, who contributes to juridification by an 
increased production of laws. This form of juridification is called legislative growth, which can be seen not only in the actual growth of the scope of legislation (quantitative juridification), but also in its increased detail and specialisation, which includes the outsourcing of some areas of legal regulation (the qualitative aspects of juridification). Power thus lies with the legislator, who is able to take decisions regarding political goal setting.

The second form of juridification is administrative, with the production of sub-legal law decrees, circulars, resolutions, etc. Bureaucratisation, then, means the 'law' created by the administration. According to Max Weber's ideal type of a legal-bureaucratic leadership, all such administrative actions must be traceable back to a legal basis. The starting point here is Max Weber's classic differentiation between 'formal' and 'material' legal rationality. Formal legal rationality is marked by precisely formulated conditions and legal rules applied according to clearly defined principles, and predictable decisions are expected. Weber regarded the modern European law of his time as 'formal rational'. The exercise of formal rationality is thus associated with the modern era's rationalisation processes by, amongst other things, giving rise to a legal profession, a legal system, legal doctrines, and so on.

The reality of administrative action has, over time, departed to a significant degree from this ideal: today it is primarily characterised by the enforcement of rules by non-jurists or non-judicial rule-appliers. This produces different, often incompatible, legal cultures as regards the application of the law (Mathiesen 2005, p. 231ff.). Moreover, modern interventionist law often features open means-end programmes (often general clauses) rather than precisely programmed conditional programmes. These give wide scope to the administration.

The third form of juridification takes place through judicialisation, which describes the production by the judiciary, via its legal practices, of norms with governing potential.

In legal discussion of the concept of juridification, as I have already indicated, growth is the phenomenon most often identified. Flexibilisation is considered as a strategy to deal with supposed overmanaging. Thus there are discussions about decentralising management tasks, switching from detailed rules to framework regulations, as well as 
using general clauses and indeterminate legal concepts (flexibilisation in a narrower sense). But, what qualitative changes in the legal structure has this juridification entailed? Gunther Teubner suggests problematising the processes of juridification in terms of the particular conditions of the interventionist state. He investigates how these processes correspond to social areas with different political and social structures (Teubner 1985, p. 295). Such an expanded, not exclusively, juridic perspective focuses on, and calls for, 'alternatives to court'. Nils Christie (1977) can be mentioned as a proponent of such thinking. In his trailblazing article written in 1977 Konflikt som eiendom [Conflict as property] he traces how juridification can be seen as a process whereby human conflicts are torn from their living context through formalisation; conflict is denatured through its legal treatment. Christie speaks of 'conflict theft' - which prevents those actually involved in the conflict from resolving it. His conclusion is that the conflict should be given back to the actual parties involved in it.

In the final book by the research group, we find several definitions clarifying their interpretation of juridification, and its consequences for democracy:

Social and cultural problems are increasingly formulated as legal claims. Ever more areas of social life have become subject to legal regulation, and the regulations are in many areas more detailed ... Juridification is expressed at different levels, nationally and internationally. Since the 1990s a number of laws has been passed in Norway establishing rights to health services, welfare and education; equality rights and the rights of cultural minorities have been expanded ... Juridification means that more areas and more details of social life are regulated by laws and directives, that the power of courts and other legal institutions to make decisions increases at the expense of political and administrative bodies, and that interests are increasingly formulated as legal claims. (Østerud et al. 2003, p. 33, 116)

In other words, the research group identifies both quantitative and qualitative growth in juridification through the establishment of rights in various areas of welfare. This happens nationally and internationally. According to the analysis of the research group, what is positive in this 
development, namely the fact that citizens have been granted rights and services, comes at a heavy cost to the democratic system.

Because of developments in the law, the centre of gravity has shifted away from citizens organising to influence political decisions, to the individual user/ consumer of the legal apparatus available when interests are to be claimed. This is one of the central arguments of the research group: that the power of elected bodies is transferred to rights-holders and the courts and that local democracy is therefore weakened (ibid., p. 33). This being a central claim of the research group, I will give several key quotes from their report:

Many of the general welfare rights are to be implemented at the municipal level. Even though many of the laws are imprecise in their allocation of rights, they limit the scope for local autonomy. (ibid., p. 33)

To expand on the research group's claim regarding the weakened state of local democracy due to juridification: the problem for local democracy does not lie solely in the establishment of rights, but also arises from the fact that these rights involve a strain on municipal budgets, so that 'not all rightful claims can be fully satisfied at the same time' (ibid., p. 33). Here lies a great potential for unequal access to the new rights, which according to the research group, is linked to people's individual situations and their ability to mobilize their rights:

Thus new and unintended forms of inequality arise, where opportunities for pursuing one's case through the mass media and courts may be decisive. Juridification creates a growth in the market for legal services, while the welfare and care professions are squeezed between growing demand and insufficient budgets. (ibid., 33)

In the researchers' analysis, it is local democracy (including the welfare and care professions) which is the 'loser' from growing juridification. If this analysis is extended to access to justice itself, to take an actor perspective, then the 'loser' is precisely the person who is wholly unable to pursue his or her case, or who can only do so to a limited extent-namely people who are disadvantaged, marginalised, or law-dissociated. There are, however, several 'winners'. In the case of Norway, these include actors 
involved in the legal system (and other supervisory bodies)_-judges, lawyers, and jurists:

This implies that the courts or court-like bodies are increasingly influential at the expense of the legislative branch, and that the separation between legislation and the interpretation of the law is being blurred ... In the case of conflict, the regulations have to be interpreted, and different rules are weighed against each other. In this way too courts and other parts of the legal system increase their power and authority. (ibid., p. 33, 116)

The courts and court-like actors are not the only winners. There is more to the concept of juridification, and this is the power of the legal model (Brinkmann 1982): 'The concept of juridification implies that legal language and decision-making methods have annexed other areas, such as the political or pedagogical' (ibid.). This development is not happening only at the national level. The research group was also deeply concerned about the continuing constraining effects of international developments:

When, in ever more areas of life and society, rights are conferred through a constitution or through the incorporation of international treaties, the scope for action of elected bodies is reduced ... The EEA-agreement means Norway is bound by the EU's directives and regulations in all areas covered by the agreement. Through supranational court interpretations of treaty clauses and common law, Parliament's ability to draft independent legislation declines in more and more new areas. (ibid., p. 21, 33)

In other words, the group's central argument on the shift of power to the courts focuses on international legal developments as represented by supranational courts such as the European Court of Human Rights or the European Court of Justice (ECJ) and European Free Trade Association (EFTA) courts; international treaties such as the EEA-agreement or World Trade Organisation (WTO) regulations and human rights conventions.

Juridification here, then, has been loaded with a negative conceptual content. However, one of the group's core researchers, Hege Skjeie, expressed a separate, dissenting opinion, maintaining that rights may 
contribute to strengthening the democratic process. Her central argument is that various human rights, and other social rights, can help ensure that groups with less economic and social power have an equal opportunity for democratic participation. She lays particular emphasis on the 'significance in terms of gender politics of rights policies and rights doctrines', which provide 'opportunities for individual and collective empowerment' (NOU 2003, p. 19, 75). This is very interesting from a legal policy perspective as it suggests a great potential for improving the legal opportunities of marginalised groups. So here, juridification has a positive connotation, one also to be found in the view taken by Rüdiger Voigt in the 1980s. Voigt recognises the potential both to increase and to limit freedom of juridification, in the individual and structural planes:

Does juridification always mean a curtailment of liberty for the individual, or is it possible in at least certain policy areas to say that we are dealing rather with a tendency to ensure individual liberty (for instance, by ensuring social rights)? And is the curtailment of political scope for action (for instance, through depoliticisation) necessarily a consequence of juridification, or in certain circumstances can it contribute to expanding the scope for reform politics? (Voigt 1980, p. 10, my translation)

This question has also been raised by Detlef Schulze (2005), who asks whether 'the man in the street' himself contributes to processes of juridification. He questions the thesis that the juridical perspective and everyday life are separate areas only superficially linked to each other, suggesting that, in certain situations, it is precisely 'the man in the street' who may independently demand 'juridification'. He calls this positive, or partly emancipatory, form of juridification performative juridification, as opposed to its restricting deformative twin.

The research group's view that juridification has had negative consequences for the Norwegian democratic system has been criticised. For reasons of space, this critique cannot be fully explored here, but some of the points of contention will now be briefly mentioned. ${ }^{4}$ Andenæs (2006, p. 587ff.) is sceptical about the courts' alleged growth in power, and, among other things, points out the stability of the number of cases heard 
in the period from 1950 until today. Moreover, the great increase in the number of jurists in Norway (1815: 329; 1960: 6600; 2002: 14,000) does not demonstrate a transfer of power from politicians to others, but is rather a sign of a more complex and confused legal situation resulting from globalisation. Blicher and Molander (2006, p. 601ff.) criticise the research group on the grounds that they do not treat juridification in a 'sufficiently differentiated fashion and thereby close the discussion on juridification, in both descriptive and normative terms.' Feiring criticises the research group's thesis on juridification in relation to welfare policy for taking a mainly quantitative perspective. Rights will only be able to limit political freedom of action if they are strong, and also provide strong rights protection (Feiring 2006, p. 577). All in all, the research group paints a 'pessimistic picture of the future of democracy'. As has been mentioned, this is linked to the negative conceptual connotations of their view of juridification. Their analysis is in line with the dominant message of the critical debates on juridification in Germany in the 1980s, which can be understood as a reaction to the disappointing results of the eagerness for social-democratic reform in the 1970s. Besides quantitative and qualitative claims regarding the growth in legislation, claims were also made in these debates that it was bringing about large-scale regulation of the last remaining autonomous areas of human action, along with judicialisation and a de-democratisation of politics through the continual increase in the use of the courts.

\section{Habermas' Concept of Juridification and Legal Policy Proposals as Seen by Norwegian Legal Aid Research}

Jürgen Habermas took this debate further, and sharpened it by claiming that there is an ongoing 'colonisation of the lifeworld' (Habermas 1981, p. 522f.; 1987, p. 356ff.). He argues this results from an eagerness for legal regulation, which also gets directed at remaining non-regulated and intimate areas. Here, too, juridification takes on deeply negative connotations. 
Kirchheimer had, as we have seen, narrowed the juridification concept to apply to the phenomenon of the Weimar Republic and, thematically, to (labour) law and politics. Further, developing this thematic concept, Habermas generalises the notion of juridification in two ways. First of all, he disengages the concept from the historical association with the Weimar Republic. He then uses it in an expanded perspective to analyse the relation of law to politics, and to identify legal expansion processes in a number of partial social systems, such as economic and education systems. The problems of the welfare state in relation to the expansion of the law are identified as a 'colonisation of the lifeworld' (Habermas 1981, vol. 2, p. 522ff.; 1987, p. 356ff.). Habermas identifies four phases of juridification: the first determines the shape of the bourgeois state in the era of absolutism in Western Europe. The second leads to constitutional government such as the monarchy in Germany in the 1800s. The third produces the democratic constitutional government seen in Europe and North America after the French Revolution. The last phase shapes the social and democratic constitutional government that arose from the struggle of the European labour movement during the 1900s.

This last phase has a liberty-granting character, from the perspective of both citizen and the democratic legislator. Habermas does not, however, consider this to apply to all social governmental regulations. Governmental welfare policy is marked by ambivalence between guaranteeing and denying liberty (ibid., p. 531, 361). In the field of governmental welfare policy Habermas discusses this idea under the heading "juridification and bureaucratisation as the boundaries of welfare policy'. In the case of legal rights to sickness or old age benefits, these represent progress compared with poor relief, but on the other hand those entitled to social security pay a high price in terms of the encroachment on their lifeworlds. 'These costs ensue from the bureaucratic implementation and monetary redemption of welfare entitlements' (ibid., p. 362). This is linked with the legal necessity to lay down rights for individual claims under carefully specified general conditions. The individualised regulation of old age pensions can have negative consequences for holders of the rights and their relation to their own local communities; for instance, it may affect the willingness of the surroundings to give additional assistance. The specification of legal conditions is once again associated with a significant compulsion 
to redefine everyday situations. Finally the problem-solving of the administration is peculiar in the sense that it abstracts human beings from the situation, to subsume them under the rule and treat them administratively. In other words, the administration must be selective.

Kjersti Ericsson has described this problem in relation to the child welfare services, as an example of the juridification of social work. She writes:

'Child welfare services have to evaluate concrete family relations and protect the good of the individual child. As a public body the service must at the same time function according to the principles of justice and the rule of law ... But it is problematic if juridical language becomes norm-creating for the way child welfare problems should be handled and understood.' (Ericsson 1998, p. 187).

According to Ericsson, the problematic lies precisely in that transition point where jurisprudence goes from representing 'gateways' to delivering a rule-bound, systematised thinking that becomes a dominant 'pattern of understanding' — one that 'phenomenalises' the lives of children in the operationalisation of juridical thinking, without recognising the unique and many-faceted nature of the context they are in. Ericsson's analysis also provides a good example of the functional limits of the law, where certain juridification processes relating to alternative problem-solving structures-'everyday meetings between social worker and client' (ibid., p. 193) - turn out to be inadequate because they require too much of the governing capacity of the law (Teubner 1985, p. 292).

The fundamental basis of the juridification debates, in relation to the limits of governmental steering policy and the function of the law, has, in recent years, become less dominant in the German debate. This is particularly true for Habermas, who has clearly changed his opinion. In his 1992 book 'Faktizität und Geltung' ('Between Facts and Norms', English transl. 1996 from Habermas 1992), he dissociates himself from the view that juridification has a generally problematic - socially disintegrativestructure in the field of social law (Habermas 1992, p. 502 fn. 47): According to this thesis, the governmental promise of serving social integration by appropriate juridification efforts would, in fact, lead to the 
disintegration of the life relations replaced by legal social integration (Habermas 1985 II, p. 534). This thesis is one no longer espoused by Habermas.

In 'Faktizität und Geltung' (Habermas 1992), there are also interesting discussions of legal policy and the sociology of law on the possibilities and limitations of disadvantaged groups in relation to legal strategies. Habermas' point of departure is that the complexity of the law means that the user needs a high level of competency, which is usually lacking.

The law can only be effective if users are sufficiently informed and able to concretise their rights:

'The competence to mobilize the law already depends in general on formal education, social background, and other variables (such as gender, age, previous courtroom experience, and the kind of social relationship affected by the conflict). But the access barriers are even higher for utilizing materialized law, which requires laypersons to dissect their everyday problems (regarding work, leisure and consumption, housing, illness, etc.) into highly specialized legal constructions that are abstractly related to real-life contexts.' (Habermas 1996, p. 411)

Habermas calls for a compensatory legal protection policy that 'strengthens vulnerable clients' legal knowledge, their capacity to perceive and articulate problems, their readiness for conflict and, in general, their ability to assert themselves' (ibid.). Habermas expects a strengthening of the countervailing power of social interests, both in the form of conventional measures such as legal protection insurance, free legal aid and 'collective modes of implementing the law' (ibid.). Among these are community complaints and class-action lawsuits, and the provision of ombudspersons and other conflict resolution measures. However, it is important, if one remembers his starting point, that the client should not be completely disempowered or forced into the role of the passive recipient of legal aid. According to Habermas, this can only be counteracted:

'if collective legal protection, besides relieving the strain on individuals through competent representation, also involves them in the organized perception, articulation, and assertion of their own interests. If the above 
proposals are not to further exacerbate the loss of voice in the welfare state, then affected citizens must experience the organization of legal protection as a political process, and they themselves must be able to take part in the construction of countervailing power and the articulation of social interests.' (ibid.)

Legal aid is thus politicised, and attributed with the potential to be a countervailing power, if the actual aid recipient is involved in the process of formulating policy.

At this point it is important to rehearse some of the central findings of Norwegian legal aid research, to provide empirical illustration of the theoretical statements of Habermas. First, there was the discovery of a great unmet need for legal aid, particularly amongst disadvantaged groups. Second, the social distribution of the unmet need for legal aid was skewed. There was a very strong correlation between lack of education and the need for legal aid. Third, it was shown there had to be a strong 'proactive' element to legal aid, in order to uncover people's problems. Fourth, the best and most proactive legal aid was always confronted by a fundamental limitation: particular problems may be solvable, but not the actual foundation of the problems: poverty itself could not be changed. As the authors of a classic 1971 legal aid study put it, this is '... an expression of how it is when some are poor and some are rich, a condition by and large in accordance with prevailing law ... Their fundamental problem is to escape poverty.' (Eskeland and Finne 1973, p. 214) This analysis cannot be challenged even now that Norway has a system of free legal aid, as it is less 'free' than its name suggests. The system has access barriers, and only those with low incomes and little wealth are entitled to free legal aid. The system is also excess-based and does not apply to cases in many areas, such as those against the public administration (see Chap. 2 above). In 2005, when the Oslo Office for free legal aid, then the only one in the country, was evaluated, researchers found almost $50 \%$ of requests did not fall within the scope of the law for free legal aid (Andenæs et al. 2005, p. 31). It took a long time to convince politicians that the report's findings were meant as a criticism, not of how the office was working, but of the serious defects of the Legal Aid Act. 


\section{The Development from Weber's Formal Rationality to the Procedural Rules of the Welfare State and the Consequences for Those Seeking Justice}

As Habermas has shown, juridification must be viewed in a wider historical context, to see how the law changes character and function in step with general societal changes. As we have seen, he identifies four juridification thrusts that show how 'modern' law has responded to global societal changes. Continuing this line of thinking, on the basis of a problem analysis of juridification and its limits of operation, Teubner makes two inferences he sees as substantial. The first of these is that one should concentrate on social state juridification, where the law as a governing tool has an intervening and compensatory function. In such circumstances, a proliferation of norms is not so much a problem for the law, as for the welfare or interventionist state. The second consequence is that because of the complete differentiation of different life areas in a legal form, there can be no talk about developing a strategy based on deregulation or dejuridification. The welfare state's spur to juridification must be accepted as a historical fact, without losing sight of its 'dysfunctional consequences' (Teubner 1985).

The question becomes how the law itself changes in the particular welfare state juridification. Earlier, I have mentioned Max Weber's differentiation between a formal and a material legal rationality. Weber argues that formal rationality is threatened by unmodern material rationality such as 'ethical imperatives, utilitarian or other prescriptions or political purposes', which go against formal rationality's logical abstraction (Weber 1967, p. 125). The internal quality of the legal culture will therefore suffer 'if sociological and economic or ethical considerations are utilised instead of juridical concepts' (ibid., p. 346). In the age of Weber, such material tendencies in law appeared particularly as social demands in democracy. Although these tendencies in Weber's age can be considered marginal, a materialisation of formal law represents the 'dominant development trend', after Teubner (1985), in welfare law juridification. 
A significant structural factor in welfare law juridification is its focus on the purpose of the law. Formal law's rule orientation is in favour of an instrumental orientation in retreat. Nonet and Selznick describe this development as 'sovereignty of purpose' (1978, p. 78ff.). As an answer to formal law's internal crisis, this responsive law is more open and flexible, and more able to respond to the needs of particular circumstances. It is the autonomous processes in law itself that inevitably produce dogmatic structures and forms of argumentation, as well as conflict resolution methods and participation models. These characteristics develop a dynamic whereby formal law is destroyed and reconstructed through incorporation of the new-responsive-law's attention to needs, sociological orientation, and political participation (Nonet and Selznick 1978). This is precisely what Weber identified as the 'materialisation' of the law.

Teubner calls the interventionist welfare state's new legal form 'regulatory law', and describes it thus:

'In its function it is geared to the guidance requirements of the social state, in its legitimation the social results of its controlling and compensating regulations are predominant. In its structure it tends to be particularistic, purpose oriented and dependent on assistance from the social sciences.' (Teubner 1987, p. 19)

As the last step in his analysis, Teubner discusses whether regulatory law has now reached its limits. As we have seen, Weber pointed out two contradictory developmental tendencies in law. One is continued specialisation and professionalisation in the legal system that extends its formal aspects. The other is determined by the 'material' demands of the social state. From a systems theory, Luhmann-inspired perspective, this is about a conflict between, on the one hand, the function of the law, which requires specialisation in order to react to the expectations of society, and on the other hand, the regulatory output of the law demanded by the systems in their surroundings.

According to Luhmann, the legal system's 'formalisation' will increase to such a degree of autonomy that one may speak of autopoietic selfreference. As is well known, Luhmann underwent a so-called paradig- 
matic shift (autopoietic turn) around 1980. General systems (such as politics, the law, the economy, science, the mass media, religion, etc.) were no longer exclusively characterised as system-environmentdifference, but as so-called self-reference or autopoiesis. By this, Luhmann means a state of affairs where the selection mechanisms necessary for the formation of a system become ever more complicated. Systems become more and more normatively closed, refer to themselves, and organise everything on the basis of themselves. This is what is meant by selfreference or autopoiesis. For Luhmann, the necessity to reproduce themselves constitutes the central factor in the development of systems. From this viewpoint, the legal system is understood as a closed system, constantly preoccupied with its own autonomy and the reproduction of autopoiesis:

'Their characteristics are: that they themselves produce and delimit the operative unity of their elements (i.e. for our area: legally relevant events and decisions) through the operation of their elements and that it is precisely this autopoietic process that lends its own unity to the system.' (Luhmann 2014, p. 281f)

For the law, this means, among other things, that such a system produces, and reproduces itself. The law supports its validity solely by normativity and thereby disconnects all extra-judicial circumstances such as politics, morals, and science from natural law justifications (Calliess 2006 , p. 64). At the same time, the law's growing formalisation increases its materialisation. This is related to its specialisation within the system, where it keeps forming norms and procedures, which, in turn, may be used for social state governing purposes. Teubner formulates it in this paradoxical fashion: 'Law, by being posited as autonomous in its function-formality-becomes increasingly dependent on the demands for performance from its social environment-materiality.' (Teubner 1987, p. 20) Put another way, when it is instrumentalised for welfare state purposes, modern, autonomous, highly formalised, and professional law becomes subject to specific demands both from the political system and from the areas of life which are to be regulated. In this conflictual relationship, between increasing autonomy and increasing dependence, 
Teubner sees modern juridification's necessity and problematics (ibid., p. 315).

Thus, as Luhmann and Teubner see it, the problem for modern law lies in the contradiction between the growing autonomy of systems and the parallel increase in dependence. Once different systems such as the economy, the law and politics are so strongly characterised by self-reference, they are no longer accessible to each other. So, for example, politics makes binding decisions within its own sphere of power, while the law relates exclusively to its demands for normativity in the same way that the economic system relates to demands for competition and the money economy. External demands are only recognised by systems if they satisfy the systems' internal logic and selection criteria.

'In terms of environmental influences on law, this means that even the most powerful social and political pressures are only perceived and processed in the legal system to the extent that they appear on the inner 'screens' of legal reality constructions'. (Teubner 1987, p. 20)

From a steering perspective the effect of the regulatory or interventionist law must be assessed as neutral, within the limits of the individual system's self-reference. This relation is described by Teubner as a regulatory trilemma: 'Every regulatory intervention which goes beyond these limits is either irrelevant or produces disintegrating effects on the social area of life or else disintegrating effects on regulatory law itself.' (Teubner 1987, p. 21)

The situation is now even more complicated, as juridification processes constitute not only a relation between the legal system and the area of social life to be regulated, but also a relation to the political system. Thus juridification must go through a complicated process of many-faceted political steering decisions, followed by legal operationalisation and applications, and finally implementation. Many problems may arise, due to the insufficient 'structural coupling of politics, law and the area of social life' (Teubner, ibid.).

What Teubner doubts is whether the law and politics are at all capable of ensuring the integration Durkheim expected to result from organic solidarity_ given the problematic framework we have discussed 
and the systems' often disintegrating and hence incompatible internal logic. Politics and the law seek a solution by not attempting to standardise social conduct directly, but rather governing it more indirectly through legislation. This can be seen in the introduction of legal procedural elements in the law following a formal legal starting point. Proceduralisation (Röhl and Machura 1997) is a collective concept describing the role of the law in promoting the establishment of social systems that can learn on the way and can be controlled (Teubner 1987). Such procedural rules or legal frames declare which groups are to be brought in to solve the problem in question. Control must happen in the particular field requiring regulation, through persons located there.

I want to conclude by looking at the example of the Norwegian extra-judicial conflict resolution system for consumers. This can be viewed as an example of 'hybrid regulation forms, where the public, industry and consumers meet together to administer, interpret and shape current legal practice' (Stø et al. 2007, p. 11). The purpose of these forms of procedural regulation is both to ease the burden on the courts, and to effectivise and legitimise the execution of the law 'by affected parties themselves finding amicable solutions and interpreting the relevant law' (ibid.). This self-regulation of industry and consumers is inspired by the state's acknowledgment that it is unable to regulate everything itself: 'In the real world the state often lacks sufficient knowledge and/or instruments of power and is dependent upon the cooperation of the regulated to be able to regulate and rule society' (ibid.). This modern form of conflict resolution by procedural or hybrid forms of regulation has resulted in most consumer complaints being solved by the Consumer Dispute Board [Forbrukertvistutvalget] - which handles consumer complaints in the areas of the Consumer Purchase Act, Tradesman Services Act, and the Return of Purchases Act, and a number (22 in total) of voluntary, sector-specific claims boards such as the Banking Complaints Board, Dwellings Dispute Board, Insurance Complaints Board, Complaints Board for Car Hire Services, Parking Complaints Board, and so on (ibid., p. 20).

But proceduralisation cannot stop weak rights being ineffective-in this case, the rights of consumers-when they cannot compete with the 
legal position of the opposing side. The practices of the Insurance Complaints Office (ICO), which opened in 1971, will illustrate this point. The office is also the secretariat of the Insurance Complaints Board. The ICO provides free legal aid to insurance customers making complaints, through an agreement between the Norwegian Financial Services Association, the Consumer Council, and the Confederation of Norwegian Enterprise. The office is financed by the insurance industry, on a per incident basis, in relation to the numbers of cases reported to the ICO. The individual boards are chaired by an independent jurist. The boards also include two representatives from the Consumer Council and two from the insurance industry. The evaluation report of the Norwegian extra-judicial dispute resolution system, quoted above, concludes that 'the system works well in the main' (Stø et al. 2007, p. 79), but problems regarding the neutrality and independence of the systems are pointed out.

A general problem with such forms of regulations can occur when private actors are involved in regulation and conflict resolution in areas where those opposing them are weak: when, for instance, the interests of private industry dominate conflict resolution by defining and interpreting existing laws, this can help cement already existing power discrepancies between heavy industry and weak consumer interests. In such cases, political intervention is required to limit the legal frames of procedural rules relating to the interests of heavy industry. So, proceduralisation, and a stronger focus on autonomy, are not the final solution: "Inexactness" of legal regulation and increased coordination costs would almost inevitably be side-effects of a "proceduralization" of law.' (Teubner 1987, p. 39).

\section{Conclusion on Mobilising the Law}

Generally speaking, the ability to mobilise the law is dependent on having information about the law and competence. In the absence of this, compensatory legal aid is required. Examples of this include legal protection insurance, free legal aid, the collectivisation of implementing the law, and ombudspersons. Juridification of this positive-emancipatory- 
variety has potential as a social countervailing power. Compensatory legal aid requires a competent deputy, but also a strengthening of the justice seekers' participatory abilities, so they avoid disenfranchisement (i.e., to achieve inclusion). Compensatory policies are not unlimited. Legal aid projects with a proactive profile are rare, because they demand considerable resources. Proactive legal aid is thus selective; it is used to discover where the real need is.

However, access to the law is not only a problem to do with class. Proceduralisation and more indirect forms of government through the introduction of elements of self-regulation show that there are not only weak justice seekers, but also weak rights. This applies to consumers generally, regardless of their social status. This means that the elements of self-rule in procedural regulations do not hinder, but possibly help cement inequalities of power in the world of producers and consumers.

What can be done in addition to the remedial actions already discussed, in order to improve the abilities and opportunities of (lawdissociated) citizens to mobilise the law? I have presented some proposals elsewhere (Papendorf 2012, p. $261 \mathrm{ff}$.):

- Mandatory training in school The law is increasingly complex, and this makes it difficult to mobilise. This is particularly true for law-dissociated citizens. To alter this situation it is important to increase knowledge and understanding at school level, to help pupils to utilise the law where this seems useful as a problem solving strategy.

- Needs thinking must be integrated into legal access for lawdissociated citizens

The Finnish law theorist Thomas Wilhelmsson introduced the idea of a 'social civil law' (Wilhelmsson 1987). His revolutionary idea was to integrate needs thinking into contract law, where there is often one strong and one weak party. This real difference (despite formal equality) in the contractual relationship would, he argues, be ameliorated by introducing needs-oriented principles giving precedence to the interests of weaker parties in the contractual relationship. 
- Increasing the knowledge of certain groups The Norwegian women's legal aid organisation, JURK, seeks to provide legal information to minority women. Legal information is given as part of an empowerment strategy to enable them to mobilise legal aid independently. This strategy should be expanded and become mandatory for the immigrant population in general.

- Compensatory legal aid must be extended and expanded. Compensatory legal aid requires both a competent deputy, but also a strengthening of justice seekers' participatory abilities, to protect them from disenfranchisement. Proactive efforts are needed to reach all justice seekers, including those suffering from poverty, drug problems, and discrimination.

\section{Notes}

1. Makt- og demokratiutredningen, hereafter referred to as 'the research group'.

2. All quotes translated from the Norwegian by the author unless otherwise noted.

3. Originally, the concept of juridification differed from the one commonly used in contemporary debates. Otto Kirchheimer (1928) used the term first, but as a concept relating to political struggle in the labour rights debates in the Weimar Republic. Kirchheimer criticised the ongoing juridification of labour conditions, which led to a neutralisation of former political class conflicts (ibid., p. 596ff.).

4. For a more thorough presentation of the critique, (see Papendorf 2012, p. $31 \mathrm{ff}$.$) .$

\section{References}

Andenæs, K. (2006). Om maktens rettsliggjøring og rettsliggjøringens maktpotensial [On the juridification of power and the power potential of juridification]. TfS 4, p. 587ff. 
Andenæs, K. et al. (2005). Kontoret for fri rettshjelp: Retshjalp til ubemidlede. Evaluering av en Oslo-institusjon gjennom 112 ar [The Office for Free Legal Aid: Legal aid for the indigent. Evaluation of an Oslo institution over 112 years]. Oslo.

Blicher, L., \& Molander, A.. (2006). Maktutredningens rettsliggjøringsbegrep [The juridification concept of the Research Group on Power and Democracy]. TfS 4, p. $601 \mathrm{ff}$.

Brinkmann, J. (1982). Konfliktsosiologi [Sociology of conflict]. Oslo: Institutt for rettssosiologi.

Calliess, G. P. (2006). Systemtheorie: Luhmann/Teubner. In B. Christensen \& A. Fischer-Lescano (Eds.), Neue Theorien des Rechts (pp. 57-75). Stuttgart: UTB.

Christie, N. (1977). Konflikt som eiendom [Conflict as property]. Tidsskrift for Rettsvitenskap, 90, p. $113 \mathrm{ff}$.

Ericsson, K. (1998). Regler og relasjoner i barnevernet [Rules and relations in the child welfare services]. Tidsskrift for velferdsforskning, 1(4), p. 187ff.

Eskeland, S., \& Finne, J. (1973). Rettshjelp [Legal aid]. Oslo: Pax Forlag. Feiring, Eli. (2006). Demokratiet og rettsliggjøring av velferdspolitikken [Democracy and juridification of welfare policy]. TFS 4, p. $575 \mathrm{ff}$.

Habermas, J. (1981). Theorie des kommunikativen Handelns. Bind 1: Handlungsrationalität und gesellschaftliche Rationalisierung. Bind 2: Zur Kritik der funktionalistischen Vernunft. Suhrkamp: Frankfurt/Main (3rd ed.) 1985. English translation: The theory of communicative action, volume 1. Reason and the rationalization of society. Boston: Beacon Press, 1984. Vol. 2. Lifeword and system: A critique of functionalist reason. Boston: Beacon Press, 1987.

Habermas, J. (1985). Dialektik der Rationalisierung. In Die neue Unübersichtlichkeit (p. 167ff). Frankfurt/Main: Suhrkamp.

Habermas, J. (1992). Faktizität und Geltung. Beiträge zur Diskurstheorie des Rechts und des demokratischen Rechtsstaats. Frankfurt am Main: Suhrkamp. English translation: Habermas, J. (1996) Between facts and norms. Contributions to a discourse theory of law and democracy. Massachusetts: MIT Press.

Kirchheimer, O. (1928). Zur Staatslehre des Sozialismus und Bolschewismus. In $Z f P$, p. $596 f f$.

Luhmann, N. (2014). A sociological theory of law (2nd ed.). Oxon: Routledge.

Mathiesen, T. (2005). Retten i samfunnet. En innforing i rettssosiologi [The law in society. An introduction to the sociology of law]. Oslo: Pax Forlag. 
Nonet, P., \& Selznick, P. (1978). Law and society in transition. Toward responsive law. New York: Harper \& Row.

NOU. (2003). 19 Makt og demokrati. Sluttrapport fra Makt- og demokratiutredningen [Power and democracy. Final report of the Research Group on Power and Democracy].

Østerud, Ø. (2006). Makt og urett-kommentar til en rettsteoretisk kritikk av Makt- og Demokratiutredningen [Power and injustice-Comments on a law theoretical critique of the Research Group on Power and Democracy]. Lov og rett, 45, p. 106ff.

Østerud, Ø. et al. (2003). Makten og demokratiet. En sluttbok fra Makt-og Demokratiutredningen [Power and democracy. A final book by the Research Group on Power and Democracy]. Oslo: Gyldendal.

Papendorf, K. (2012). Rett for alle? Rettsliggjøring og rettsferne personers mulighet til a mobilisere retten [Law for all? Juridification and possibilities for lawdissociated persons to mobilise the law]. Oslo: Novus forlag.

Röhl, K., \& Machura, S. (Eds.). (1997). Procedural justice. Aldershot: Ashgate.

Schulze, D. G. (2005). Verrechtlichung-Deformation oder Performation? Überarbeiteter Vortrag auf der Tagung "Die Jurisprudenz zwischen Verrechtlichung und Rechtsferne der Alltagspraxis" am 17./18. Juni 2005 in Düsseldorf.

Skjeie, H. (2003). Særuttalelse fra Hege Skjeie [Separate opinion by Hege Skjeie]. In NOU (2003):19. Makt og demokrati. Sluttrapport fra Makt- og demokratiutredning.

Stø, E. et al. (Ed.) (2007). Å få rett—når du har rett. En diskusjon av de frivillige klagenemndene og FTUs effektivitet, noytralitet og legitimitet [Being granted rights-When you are right. A discussion on the voluntary complaints boards and the efficiency, neutrality and legitimacy of the Consumer dispute panel]. SIFO. Oppdragsrapport nr. p. 4.

Teubner, G. (1985). Verrechtlichung-Begriffe, Merkmale, Grenzen, Auswege. In F. Kübler (Ed.), Verrechtlichung von Wirtschaft, Arbeit und sozialer Solidarität (p. 290ff). Frankfurt/Main: Suhrkamp. English edition: JuridificationConcepts, aspects, limits, solutions. In G. Teubner (Ed.) (1987), Juridification of Social Spheres (p. 3ff). Berlin/New York: Walter de Gruyter.

Teubner, G. (Ed.) (1987). Global law without a state. Brookfield/Singapore/ Sydney: Dartmouth/Aldershot.

Voigt, R. (1980). Verrechtlichung in Staat und Gesellschaft. In R. Voigt (Ed.), Verrechtlichung. Analysen zu Funktion und Wirkung von Parlamentarisierung, Bürokratisierung und Justizialisierung sozialer, politischer und ökonomischer Prozesse (p. 15ff). Athenäum: Königstein/Taunus. 
Weber, M. (1967 (1960)). Rechtssoziologie aus dem Manuskript herausgegeben und eingeleitet von Johannes Winckelmann (2nd ed.), Neuwied am Rhein und Berlin: Hermann-Luchterhand Verlag.

Wilhelmsson, T. (1987). Social civilrätt. Om behovsorienterade element i kontrakträttens allmänna läror [Social civil law. On needs oriented elements in the general discipline of contract law]. Helsinki: Juristförbundets förlag.

Open Access This chapter is distributed under the terms of the Creative Commons Attribution 4.0 International License (http://creativecommons.org/ licenses/by/4.0/), which permits use, duplication, adaptation, distribution, and reproduction in any medium or format, as long as you give appropriate credit to the original author(s) and the source, a link is provided to the Creative Commons license, and any changes made are indicated.

The images or other third party material in this book are included in the work's Creative Commons license, unless indicated otherwise in the credit line; if such material is not included in the work's Creative Commons license and the respective action is not permitted by statutory regulation, users will need to obtain permission from the license holder to duplicate, adapt or reproduce the material. 